\title{
"Writing Another Kind of Poetry": James Norman Hall as "Fern Gravel" in Oh Millersville!
}

\author{
Edward Brunner
}

I am writing another kind of poetry,

And some of my poems are beautiful to me.

I hope, someday, people will travel

To see the home of the poetess, Fern Gravel,

Like they go to Longfellow's home, and Whittier's,

And then I'll remember the day I wrote this verse.

- from "Iowa" in Oh Millersville!

The gentlest of hoaxes, James Norman Hall's Oh Millersville! (1940) is in danger of lapsing from our attention the moment we finish any of its poems. Central to his hoax is Hall's impersonation of the voice of a girl in her ninth, tenth and eleventh years who chose for herself the less-than-fortunate nom de plume of "Fern Gravel" for writing about small town Iowa in the 1900s. Since her voice was scripted to be barely audible, it is not altogether surprising that her poetry has fallen into obscurity. (That Hall has no reputation as a poet and is known primarily as the collaborator, with James Nordhoff, of the best-selling trilogy Mutiny on the Bounty (1932), Pitcairn's Island (1934) and Men Against the Sea (1934) has also not enabled its circulation.) And judging from individual poems, Fern Gravel's poetry is - it's the only word-abysmal. No anthologist would touch "Iowa," whose concluding lines appear above, and which begins: "Of all the states in our country so grand / Iowa is the best, and that is my land" (Oh 49). Over a three-year apprenticeship Fern im-

Edward Brunner teaches twentieth-century literature at Southern Illinois University at Carbondale. He has published Cold War Poetry: The Social Text in the Fifties Poem and, more recently, essays on the "adventure" comic strips syndicated in American newspapers from 1930 to 1960. 
proves somewhat. "The Voyage of the Spray" begins: "Oh, on that day the sea was just wonderful! / There were a few waves, not very high. / We were sailing in Mr. Hendrixon's boat, the Spray, / And we saw many islands passing by" (Oh 105). She has escaped the tyranny of the rhyming couplet, though not rhyme itself, and manages to create a conversational effect ("a few waves, not very high"), though she still depends on her enthusiasm to launch into a beginning. But even the very last of the poems in Oh Millersville! are the work of a neophyte.

Yet theorists and scholars over the last twenty years have been prompting us to look not just at the single poem as it stands but at the acts that lead to producing and using the poem in its larger context, its place in a sequence or a book, or a book itself as a sequence; its relationship to its own time or the time in which it professes to have been written; and its readiness to articulate itself with other ways of making contact, from the visual arrangement on the page to evoking such parallel forms of expression as the blues or the snapshot or the document. These alternate considerations, many of which emerged in a spectacular rush in 1989 from Cary Nelson's Repression and Recovery: Modern American Poetry and the Politics of Cultural Memory, 1910-1945, were designed to enter poetry into a larger conversation that placed "the social" in relation to "the aesthetic" as a powerful key term. Paula Rabinowitz, in her study of the documentary, They Must Be Represented: The Politics of Documentary, defined the social as "the irruption of the household into public view," adding that it could be "understood as the growing public-sphere activities which are akin to politics, but not quite political, akin to economics, but not quite" (6). With the scope of the poem so broadened, with its boundaries so dissolved, it necessarily enters not just into history but into a dialogue with the very idea of the historical. "All the historical moments come to us in these poems not as full narratives but in the form of a partly elided history that requires our interpretive effort if it is to have any purchase in our lives," Nelson reminds us in Revolutionary Memory: Recovering the Poetry of the American Left. "It is one of the legacies of an historically engaged poetry to give us the past in a form that is at once eloquent and incomplete" (84).

By these standards, Oh Millersville! starts to take on a shape, a role, and even a voice - albeit a remarkably divided and intricate one - all of which now begin to seem purposely encrypted by Hall, whose initial offering of just an archival moment, an amiable glimpse through a child's notebook verse into a past that would have been otherwise lost, becomes something closer to an extended sequence manqué, or a miniaturized lyrical epic. Oh Millersville! is a beguiling work that could not have been more cunningly constructed. As we are drawn into a small-town universe whose parameters we comprehend in up-close detail by looking through examples of a neophyte's verse, we are at the same time made aware of that which the observer herself apparently does not yet know: that she is continually, relentlessly, and almost obsessively pressing against the limits that the town places upon her. Inquisitive, ambitious, restless, energetic, she has a personality eager to expand its horizons and powerfully abetted by the machineries and technologies that are about to transform the twentieth century and whose presence she registers even in remote Millersville-even a trace of their existence charges her with remarkable energy. ${ }^{2}$ Hall thus places us inside the town even as our guide longs to 
be outside it; we are at the center of both an external geography and an internal territory. From half-seen glimpses and fragmentary clues, we compose an understanding of how the town operates and who Fern Gravel is.

Hall was not a happy reader of works in the twentieth-century avant-garde. He shamelessly announced he had failed to read more than a single page in Ulysses ("Ends" 209). But in Oh Millersville! he constructed out of materials that even by the 1930s were beginning to be considered unlikely tools for complex communication-metrical lines, rhymed verse, "occasional" subjects - a poetic sequence that compels our involvement and repays our attention as it cannily registers a particularly salient response to the disturbances of modernity. Even as he foregrounds the stress on a sensibility like Fern Gravel's that aspires to make art in a culture that has no tradition of artistic appreciation, Hall produces a perfect text for readers who have no time or inclination to read poetry: a pocket epic that pretends to be nothing at all, the merest of baubles, even as it silently, secretly goes about using all the resources of poetry to comment on the limits of American institutions, to sing the praises of the machine and the new technology, and to sketch a beguiling portrait of a young girl who was most certainly destined to exemplify the New Woman.

\section{One}

Temperamentally, Hall was well-suited to such an intricate charge. Although Hall had lived in Tahiti since the 1920s, producing novels that were elaborate reconstructions of historical events, he had spent his formative years as a social worker in Boston and an aviator for the Lafayette Escadrille during the Great War where he was shot down, captured behind enemy lines, and held as a prisoner of war. Unlikely blendings were his stock in trade. In an essay published in the 1930s entitled "The Spirit of Place," he records coming upon the ruins of a home on a remote Pacific atoll. The home's air of tidiness and its bric-a-brac (a small China dog that he envisages on a mantelpiece next to a ticking clock) convince him the builder came from New England. To counteract a sensation of loneliness that he associates with the long-absent homebuilder, Hall writes a poem in which, though he stands alongside a palm tree, he imagines he is knee-deep in the snow and silence of his Iowa home in winter: "Oh, kindly hills of home!," he writes in its third and final stanza, "that keep / For us who left them years ago / A wintry silence, muffled deep / In newly fallen, immortal snow" ("December" 500). If the message of this poem is that our home place never leaves us, the message of the essay that produced the poem is that under certain circumstances the spirit of even a place that is out of placeeven a New England unimaginably remote from the tropics - can be transmitted, though it must be channeled with sufficient intensity, in personal artifacts (architecture, choice of décor) and regarded by a receptive audience. And paradoxically, intricately, the result of such a moment is that it returns us not to the New England hills of the one whose presence haunts the ruin but to our own "kindly hills of home" that were left "years ago."

Hall's unwillingness to commit himself wholly to a single environment, his attentiveness to the call of another's picturesque ruin, and even his readiness to venture out of his prose framework and to resort to poetry in an effort to honor the complex- 
ity of his overlapping perceptions all betray an affinity for experiment that $\mathrm{Oh}$ Millersville! will both exercise and restrain. Such intricacy characterizes a procedure devised perhaps because no other method could so vividly catapult Hall back to his boyhood days in Colfax, Iowa, a time that was, according to the pages describing it in his posthumous autobiography of 1952, among the happiest of his long and happy life. Certainly Hall evinces not a trace of repentance in the 1946 Atlantic Monthly article in which he confessed to having authored an extremely successful hoax. Not surprisingly, that piece, subtitled, a "hoax and a confession," is less an acknowledgment of wrong-doings than a lesson in the sources of inspiration.

In his essay, Hall identifies "Fern Gravel" as a visitor who comes in a dream, a dimension over which no one can have control, and who brings him an association with a childhood memory in which he watched children singing "on the shadowdappled lawn, in the golden light of afternoon" ("Fern" 112). Her presence summons him, for who has control over their dreams? She is at once a force beyond his control and an invaluable guide to his depths: "She ... dictated so fast that I got writer's cramp.... She told me things about people in our home town that I had completely forgotten, or thought I had" ("Fern" 113). She is a reminder that the sources of creativity are profoundly mixed, beyond complete management and dependent on unlikely combinations. Hoaxing? The mind plays tricks on us, Hall asserts, and from such trickery, some make an art that retrieves from the past moments once thought lost. In his essay, Hall erases the line dividing the inauthentic from the genuine.

Hall also implies that information arrives through countless channels in the fastpaced postwar culture of 1946 that acknowledges the unconscious and that, among other things, accepts the duplicity in advertising messages. His essay does double duty, scandalously announcing his guilt and serving as a canny bit of self-promotion by declaring the existence of a cache of unpublished "Fern Gravel" poems. Hall explains that he insisted to his dream-visitor that the flow of verse she was dictating had to stop - "she wanted to make it an even hundred and deferred with reluctance to my judgment." But he adds that Fern, operating under her own laws, paid no attention "and dictated enough additional poems to have filled Volume II of the Collected Works to come" ("Hoax" 114). Passages from two "uncollected" poems that he cites in his article are, in one sense, entertaining proof that such material exists, while in another sense, they bring news that material is available for any interested publisher. Here Hall erases the line dividing the announcement from the advertisement.

If it is necessary to classify Hall's work as a hoax, it is worth emphasizing that it fits into the last of the three categories that Brian McHale devised to explain hoaxpoetry: one of the "mock-hoaxes," "meant eventually to be seen through ... typically refer[ring] to their own double nature" as both inauthentic and authentic, and "leaving it to their readers to draw the relevant inferences" (236-37). The "mockhoax" is least secretive of McHale's categories, treating its readers as having the perceptivity to wonder about its "double nature," its mix of the inauthentic with the authentic (or how it draws on inauthentic artifacts to create an authentic impression), and inviting them to interact with the material accordingly. After all, Hall's stature as a novelist rests on extracting a gripping narrative from historical documents. Producing the Bounty trilogy with Nordhoff involved research in which the collaborators consulted blueprints of the Bounty, commis- 
sioned a scale model of the ship, and examined Admiralty records and court-martial proceedings (Island313-314). With Millersville! Hall reverses this procedure: he creates the personal documents from which we construct a cultural narrative.

What is involved here, moreover, is not just the cleverness that involves salting a work with the "authenticity-effects" that K. K. Ruthven has noted literary forgers trade upon, including “" inconsequential' episodes that would be edited out of a text by any self-consciously literary author" and "vivid but 'irrelevant' details ... which are frowned upon in a functionalist aesthetic committed to eliminating superfluities" (149). The forger who is constructing what appears to be a set of documents must also shape the documents in an arrangement or sequence that will encourage us to find clues, make assumptions, and draw conclusions. Distinguishing between documents and the work of making a documentary, Paula Rabinowitz has written: "Documents may appear to be neutral sources of historical truth, but documentaries have and present values" (7). Acknowledging the neutral stance of the document, the documentarian can surround it with other, related documents that galvanize that neutrality into positive or negative valences. Especially in the Depression-era, documentary itself was a mode of presentation designed to record voices that might otherwise be lost, figures too unimportant to be noted, events that occurred on the margin. As a volume appearing to be an edition of material that uncovered an archive from the past, Oh Millersville! encouraged an approach that would disclose that which had heretofore been unavailable. The use of the documentary, then, not only encouraged a degree of participation but also promised that, within the apparently neutral or even banal portrayals that conveyed an air of ordinariness, there would be unusual finds that would repay attentiveness.

From a documentary perspective, the existence of "bad" verse is not a cause for alarm but an invitation to draw closer for an examination of some tell-tale symptom or scandal. In general, of course, with "bad" verse Hall is pointing to the limitations under which the would-be poet operated in the years just after 1900, when modernism was still in its birth-throes. But if Oh Millersville! is the product of a writer who has inherited the nineteenth-century tradition, thus exposing the limitations of the options for poets at the turn of the century, Hall has also commandeered this diminished verse to register - or even more interestingly, register almost as a semiquaver - the seismic changes that modernity is bringing. Hall anticipates John Timberman Newcomb's examples of 1900-era American poets whose mannerly verse was at times undermined by "false starts, blind alleys, and abrupt endings" (159) or even instants of incongruity, mysterious repetition, and temporary discord (see 190-245). For Fern, employing the rhymed couplet represents a veritable sign of "the poetic"; she deems it is high quality. But the "bipolar structure of the couplet," as Angus Fletcher observes, presents a "desire to define, to enclose, to delimit" (35). And as Hall shows, Fern's couplets regularly spill over the line break, refusing to submit to enclosure, as the book's first poem demonstrates:

Millersville, Oh Millersville!

This is my home and I like it, but still

I wish that once in a while I could go 
Although such writing marks Fern's amateurism, it is also noteworthy that this is her signature flaw, as if her desire to resist constraint is always present. Hall offers the typical Fern Gravel poem as a kind of bare-bones stage setting that allows for even small disturbances to be magnified as they catch our attention-even as they also appear to be no more than odd bits of ineffective writing.

Consider "The Chatauqua," a poem in which Fern demonstrates her commitment to a dutiful chronicle of the year's events. The opening of the poem appears to be a simple description of the performances she has witnessed:

The Millersville chatalkua [sic]

Was over last week,

And I heard a famous person

Who came here to speak.

It was the Reverent [sic] Sam Jones;

He is a great evangilist [sic]

Who lives in a southern state.

My mother said she wouldn't have missed

His sermon for anything.

The African Boy Choir

Sang on that first night.

The next night was the camp fire.

The third night the concert was given

By the famous bell-ringers.

Some people liked them better

Even than the African boy singers. (Oh 96)

Read as the actual work of an aspiring versifier, "The Chautauqua" has little appeal. But read as a sophisticated writer's simulation of notebook verse it invites a symptomatic approach, in the spirit of the documentary, and it bristles with information. The words misspelled (an uncharacteristic lapse by hard-working Fern) expose her lack of interest in the Chautauqua and other religious matters, whose basic terminology remains foreign to her. The "famous person" evangelist impressed Fern's mother, and her response is duly recorded, but Fern herself, uncharacteristically, has nothing to say. Perhaps most telling, though, is the contest between the "famous" bell-ringers and the "African Boy Choir," a distinction, Fern notes, that "[s]ome people" made. Were they insisting on the fame of the bell-ringers even though the choir was so much superior? What is Fern attending to in this assertion that perhaps seems unexpected to her? Were some startled, alarmed, disoriented by the quality of the singing boys? And how old were these singers who form the "African Boy Choir" - what weight accrues to the word "boy," especially in a performance setting dominated by a southern evangelist? While a number of the verbal clues provide a glimpse of Fern's developing personality (a shift away from religion, a studied silence toward her mother), others register a tense moment, an awkward instance. The apparently bland surface of an $\mathrm{Oh}$ 
Millersville! is actually rippled and distorted by forces or pressures that are invisible yet whose presence is felt.

When Hall returns us to the years between 1900 and 1905, he is, to be sure, traveling back to such memories in small-town life as he recalls, like children playing in the "golden light of afternoon" ("Fern" 112). But that light may be golden because of the aspirations that were once in its air. Hall's production recalls a moment at the turn of the new century when a new interest in regional writing ushered in strange voices, including those speaking for the New Woman, voices reworking forms that had once been relegated to minor status. The Fern Gravel chronology begins almost a decade after Sarah Orne Jewett's Country of the Pointed Firs (1896) and at the very point when Kate Chopin was writing her finest short stories, sketches, and vignettes. It coincides with the moment when the Tilbury Town poems of Edwin Arlington Robinson in The Children of the Night went from their limited printing of 1897 into an edition with significant circulation, and it is a decade ahead of the publication of Edgar Lee Masters's Spoon River Anthology (1915). This early regionalism expressed itself through voices of the marginal, including such impressive children as the monologue in "Nellie Clark" that Masters recorded, Babette's measured exchange with her godmother in Chopin's "Ripe Figs" and Sylvy's impulsive visionary moment in Jewett's "The White Heron."

But while Hall returns us to the 1900s, he is also addressing a public at the end of the 1930s, and if it is striking, for example, to glimpse the 1900-era tension between the "famous bell-ringers" and the surprising impact of the "African boy singers," it is no less striking to consider how familiar such tension still is nearly four decades later. Especially when it is approached in the spirit of the documentary, with an inclination to uncover the symptomatic, Hall's version of the awkward "authenticity-effect" is closer to that sensation that Walter Benjamin most eloquently described - that instant in which a detail from the past that might have seemed negligible in its time flares into significance when it is considered at a later time, in our new present (391). When the reading experience continually notes such junctures, such sudden interrelations between past and present, Hall has succeeded in creating a text based on user-friendly reading strategies that are remarkably engaging. Fern is not equipped to write the polished poem. She is not only unsophisticated but she lives in a transitional moment, surrounded by the forces of modernity that her inherited poetic tradition has ill-prepared her to contain. The "authenticity" in her writings, as Hall conveys it, lies in their failure to subdue the very items, events, and occurrences that poetry, when officially prepared by adult professionals, exists to suppress, or to contain through some mystification, or to naturalize out of the foreground. Such details, as staged by Hall, catch our eye or brush our ear. The failure of the "aesthetic" allows for the entrance of the "social."

\section{Two}

Even a gentle hoax entails a calculated affront. To produce "another kind of poetry" invites a reader to think about why one mask was used rather than another and what effects were chosen as deceptive strategies. At their later stage, mockhoaxes especially invite the public back stage, and it is not surprising that the most 
intriguing mock-hoax poetry is to a large extent about the making of poetry - or at least the making of the poet. Oh Millersville! is no exception. William Stott has singled out the importance in 1930s documentaries of the informant narrative that testifies to the "personal experience of an event or social condition not common knowledge" (192). These work-narratives for "all classes but the wealthy and all degrees of sophistication" included even the worker who was "not blue collar but a "brain worker"" (194). Though it could be characterized in many ways, Oh Millersville! is best described as a worker narrative about poetic labor and the toil of becoming a poet.

Hall shows Fern to have chosen a vocation for which there are no rules but endless mistakes to be made, for which there are no mentors (especially for a young girl-all her idols are male), and which must be practiced secretively. No agreement exists, at the turn of the century, as to what constitutes a legitimate poem, and Hall anticipates Joseph Harrington's description of poetry after 1900 as "not a genre with a consensus definition, but a crossing point, an indeterminate and contested space" (3). Sometimes it chronicles historical events, like the cyclone of 1896 that destroyed homes in nearby Valeria or the William Jennings Bryan campaign stop of 1900. Sometimes it dutifully records local events, like concerts by the Grinnell glee club or performances at the summer Chautauqua. Sometimes it captures personal feelings, like the disappointment felt when an inconvenient illness by Fern's father cancels a trip to Keokuk to see the Mississippi, or the anger recorded when Fern's grades for arithmetic were designated as outweighing grades for all other subjects, holding her back a year in school. Sometimes it registers scandals, like Minnie King's runaway with a mystery man, or the suicide of Mr. Reasoner "whose wife would go / To Des Moines to stay; / And Mr. Reasoner never knew / How long she would be away" (Oh 44). And sometimes it invites an escape into fantasy, as when Fern invents companions to accompany her in imaginary adventures.

One pleasure in reading all these different versions of 1900-era poetry lies in the regular appearance of moments when Fern gets tangled in a thick-textured passage that allows a glimpse beyond the limits of the poem. Here is the complete text of "Visiting-Cards" (Mrs. Smouse is the banker's wife, a progressive woman who travels widely):

My mother has had some calling-cards printed.

The reason is Mrs. Smouse.

She thinks she ought to leave one

When she goes to their house.

Mrs. Smouse was the only one

Who had calling cards before;

But now that my mother has them

I expect there'll be more.

My mother has put a little table

In our vestibule.

You leave your card there, in a cut-glass dish;

That is the rule. (Oh 99)

In "Visiting-Cards," the poem thickens after "vestibule" brings us inside the 
house but holds us as at bay in its outer reaches. No other word is so specialized, and this one's three syllables call for precise enunciation. It is as if Fern now enters a powerful new dimension, for a word so resonant with propriety institutes a new aura of authority, and it follows that an exceptional object should appear, a "cutglass dish." The shift to the second-person singular announces that protocols now exist, though only two people in town have cards to leave. But the triumphant words "That is the rule" smack of delight and satisfaction, as if we are now in the presence of knowledge that was once-mysterious and has now been mastered. The third stanza's break from the flat information that controlled the first two stanzas signals a newly thickened language. Other voices, other gestures haunt these lines. Is the voice of the last line Fern's mother? Fern herself, trying on the power that speaks on behalf of rules? Fern (happily) emulating Mrs. Smouse? Fern's mother (vainly) emulating Mrs Smouse? The reward of such poetry is that "irruption" that Rabinowitz associated with "the social." For a moment, the usually-invisible relations that knit together families and a community are rendered visible.

Oh Millersville! passes a crucial test for hoax literature: the work improves (attracts interest, generates surplus meaning) after it has been revealed to be false. If Hall had reprinted notebooks written by his younger sister (who would have been Fern Gravel's age), then all would become mere novelty, which is how the New York Times saw it in 1941, conducting its good-natured review in clunking metrics whose rhyme twanged the state's name: "You have heard of Felicia Hemans and Fanny D'Arblay; / Have you heard of the lost Sappho of Iowa?" (Thompson 13). Evidence exists that Hall did work from verse that he wrote as a child. He reproduced in his autobiography lines he had written in response to a drowning in the local river, the Skunk:

Oh lovely river, Gentle Skunk!

Beneath this shining pool was sunk

The body of a Colfax boy!

How could the stream we love destroy

The life of little Willy King

And leave his parents sorrowing?

And throw his body on the ground

Nearly a mile from where he drowned? (Island 14)

Here is the Fern Gravel version of the drowning tragedy, "The Death of Willy Keane":

Willy Keane has been drowned

And his body was found

In the river not far away.

This happened on Thursday,

The body was found Friday,

And the funeral is today.

Mr. Keane is nearly crazy

And poor Mrs. Keane is even worse.

All the grade-school children 
When he wrote as a child, Hall addressed the river with a barrage of questions. The child cannot understand how the placid river, barely a stream, could acquire such power. When Hall the adult imitated a child's way of writing, he produced a version that at first appears simpler than its predecessor. Fern seems to stretch her lines in search of a rhyme-word, while Hall the child actually finds strong rhymes. But the Fern Gravel version must be read symptomatically, as the product of an adult poet reconstructing a child-poet's personality. The opening stanza's failure to get underway, then - its lines that simply establish a setting and a time-line for an event-also suggest the child-poet's inability to process the enormity of death. Thus the outburst of emotion in the second stanza comes as a relief, as strong feelings emerge in the gestures of the bereaving parents. With this release, a communal act of mourning begins, registered by Fern as she takes her place as one of the "grade-school children" behind the hearse. Fern's report of her inclusion within the funeral procession carries a note of pride and a sense of magnitude ("all the grade-school children"). Hall records the centrality of such public events, their value in healing the town's collective pain, and the usefulness of community action. At the same time, it is noteworthy that the parents remain steeped in grief, beyond consolation, as if these traditional rituals are not as effective as they once were; perhaps they exist now for the benefit of others, perhaps for the benefit of children.

This kind of social detail, as Joseph Harrington has noted, is more usually associated with the novel than with the poem (159-168). But such exchanges, interactions and misunderstandings constitute the textures of small-town society that Hall would display through Fern's eyes: an emotionally repressed community in which ardent feelings and intense dreams were firmly and even harshly restrained through the hegemonic influence of an informal board of local censors. Art is the battleground for such conflicts, both literally and figuratively. Fern takes up piano lessons after a suggestion from her often-absent father whom she adores (he travels the state selling insurance, returning home only on weekends). But it is a trial to learn the instrument because the local teacher, Etta Kerr (Ought to Care?), brings to her lessons the kind of demanding discipline she experienced in conservatory. In one poem, Fern explains that her scheduled duet must be cancelled because, she writes gloomily, neither she nor her partner has "practiced enough yet" (Oh 68). The poem that follows, though, "Winter Music," soars with delight:

Oh, it is wonderful in Millersville

On many a winter night,

When the ground is covered with snow

And the moon is shining so bright.

You can hear the sleigh-bells jingling

Everywhere around.

I don't think there could be

A more beautiful sound.(Oh 69) 
And though countries exist where it is "summer all the time," suddenly it seems preferable to stay in Iowa and "hear the sleigh-bells chime." Hall endows Fern with the ability to hear music in what others find to be sounds, at the same time as Fern's discovery of the beauty in the sleigh-bell is a self-preserving response, offsetting the sting of the cancelled duet. Writing "Winter Music" is a transformative shift that counteracts a rejection that may have sharpened a new responsiveness to ordinary sounds. (It may be desire, then, that Fern is recording with her example of sleigh-bell music.) This distinction between classical music and the music of the everyday is revisited in a later poem that records a confrontation between Kerr and the self-taught pianist "Blind Boone" who can replay any piano piece he hears played. Kerr's efforts to stump him only spur performances from him that emphasize his superiority as a pianist. While Fern's ability to recast background noise as musical sound points toward a sense of art that might be shared with Blind Boone, just as important is the weakness this confrontation exposes in Etta Kerr, shown as ungracious in defeat, unable to concede to Boone's achievement.

Hall offers a view of a community on the verge of the twentieth century in which cultural institutions (the church, the library, the school) operate as forces of repression that exert themselves against African Americans, non-Christians, and little girls who want to be poets. But Hall suggests the readiness of these institutions to target the powerless reveals not the cruelty of the institution but its fears that its powers may be waning or ineffective. Fern is just beginning to question lessons she has imbibed from her elders. Her uncle is the town pharmacist, and he is not a churchgoer; he encourages mild gambling, and he sells bottled liquor as if it were medicinal. Fern castigates him in several poems whose moralistic stance, it seems clear, originates in promptings from the family minister, Reverend Dotson. But Fern's jeremiads gradually soften, and by the end of Oh Millersville!, a more thoughtful Fern admits that though she "cannot understand" her uncle, "He is a good man in many ways / But it will not be of any use to say / He was sorry, when he rises up / On the Judgment Day" (Oh 108). Hall subtly reveals an increasingly secular Fern beginning to attend with care to the positions held by her uncle with whom she disagrees. Even at the end-of-time moment that she envisages, she almost hears him still speaking. Indeed, more words from him are directly transcribed into her poetry than from anyone else in Millersville, including her beloved father.

Fern's interiorizing of complications is one of the subtlest aspects of $\mathrm{Oh}$ Millersville!. Hall presents a character who is torn between either following lessons administered by figures of authority or attending to the promptings of the great world - sensual, visual, aural - that is exploding around her as the twentieth century begins. As Fern struggles with her own developing sensibility, Hall shows that one advantage of writing is that it can be a place where she can declare how she feels. This freedom is startling enough, and thrilling enough, that it produces, in the earliest poems of Oh Millersville! a number of assertive outbursts, evidence of the constraints weighing upon her: "A boy in this town I really hate / Is Elmer Eccles"; "Mr. Dwight is the principal of our school./ I do not like him either" (Oh 22); "I went up to my room and shut and locked the door. / I was very mad" (Oh 24); "I was so mad / I could nearly have cried" (Oh 28). Later works, however, reveal that her 
ability to speak forthrightly need not be just dismissive. When words that are improper to speak aloud are nonetheless recorded, when direct speech is not stifled, then what can evolve is a new sensitivity to nuances of feeling. "I am getting so I hate this town," begins one later poem, "I wish I could go away" (Oh 80). As if seeing with new eyes, this poem measures not just the physical limits of the town ("We don't even have a river; / It is only a little sloo") but also the town's foreshortened possibilities. Now the death of Willy Keane lacks grandeur, as if it had been a matter of simple ignorance: "He couldn't swim and the sloo was flooded. / He shouldn't have gone in" (Oh 80).

If Fern inadvertently shows an increasingly realistic frame of mind, Hall also reveals her manipulating her own writing to compensate for distress. In eight poems at various points in Oh Millersville! Fern surrounds herself with a fictional cast of characters. One of these imaginary poems usually follows a poem that has recorded a setback or a loss. The imaginary works transpose conflicts into alternate settings that mix fantasy with reality and in which Fern acquires agency or mobility. Hall's most extreme act of ventriloquism, they offer a prophetic glimpse of what autobiographical writing by women might become, looking ahead to what Marianne DeKoven has called "cultural dreaming," in which writing becomes a passageway, an access to other selves and the other in the writer (139). Of course these poems also represent the time, place, and age of their precocious writer, and they are necessarily tangled in hesitation, compromised by doubt, and verge on compensatory excess. Yet in them, Fern always assigns herself positions of responsibility that she longs for in real life, comforting the frightened, choosing wise solutions, and earning the admiration of father-figures.

For the earliest of these, Hall shows Fern staging a situation in which anxieties are reduced to manageable conflicts. Accompanying her imaginary friends on a horse and buggy ride, the horse bolts because Fern's chum, the imaginary Lilly, who "was as nervous as could be," had screamed at a fast-moving steam engine, whistling for the exact road crossing "Where, last year, a train killed Lars / Anderson, a farmer, / Who lives south of Millersville" (Oh 16). Fern helps the adult in charge, the imaginary Mr. Hendrixon, rein in the runaway horse. Standing behind this poem, Hall makes clear, are anxieties that Fern is confronting through this scenario in which she sides with the responsible adult and transfers her own weakness and doubt to Lilly, whom she also saves. In Fern's imaginary, Lilly is always the non-Fern, the one who is the repository for Fern's self-doubt. It is Lilly who suddenly loses her nerve, professing illness, and must be taken back to the shore in the eighth of these imaginaries, "The Voyage of the Spray." Up until that moment, Fern and all her fantasy companions had been flying across ocean waves in a very South Seas-like setting.

Imaginary voyages play a substantial role in other poems. In "The Holy Land," Fern politely records the collection of unremarkable souvenirs and artifacts that Reverend Dotson brought back from a visit to the Holy Land - "a bottle of water from the Dead Sea" and two kinds of sand from different rivers. Her tedium surfaces in this poem's ultra-polite conclusion ("He has very often showed them to me" [OH 52]) as she cloaks her dismay at the idea that traveling so far away could produce such empty results. In the following poem, Fern voyages with her imaginary com- 
panions to the Holy Land's opposite, New Orleans. The journey begins as a surprise (Mr. Hendrixon "wouldn't tell us where / We were going to go"), involves stop-offs at towns to "hear the band concerts," and includes "many wonderful dishes" from the steamboat dining room that features "singing / By the colored waiters." Even the screams that the appearance of alligators elicits from Lilly exist only to be brushed away by Fern: "She thought the boat might sink. / To be so afraid for nothing / Is silly, I think" (Oh 54).

Travel-poems celebrate a mobility that identifies Fern as happily poised at the opening of the twentieth century, along with a certain level-headed fearlessness. No one is ever more eager to travel than Fern, a tendency she makes perfectly clear in the very first poem of her book. Although art is continually celebrated throughout Oh Millersville! it also has its competitors. The transformative power of art fades when contrasted with the machines just beginning to open the world to anyone craving new experience. One of Fern's earliest poems records the delight she takes in pressing an electric bell to summon the bellboy to her family's hotel room in Des Moines. Technological change is not simply, in Hall's presentation, an inevitable stage in progress but an emotional encounter from which some will emerge more happily than others. One of the last poems in Oh Millersville! lists the modern devices in the home of the wealthy Smouse family, such as hot running water, a furnace, and a nickel range in the kitchen, but if the poem begins by describing a home, it swerves to end with a very different catalogue, listing places Mrs. Smouse has been able to visit:

Whenever she wishes she can go

To cities like Chicago and Omaha and St. Joe.

When she travels she sleeps in the sleeping-car

And has her meals in the dining-car.

Last winter she went to Los Angeles

And picked oranges right off the orange trees,

And she went to San Diego and saw the Pacific Ocean.

She can go where she pleases whenever she takes the notion.

(Oh 92-93)

What does this emphasis on travel say about the complications of small-town life? They are to be escaped. They may be resolved by initiating a public role for women, an expanded education, and other social reforms. Meanwhile, those like Fern who cannot compromise will simply go elsewhere. Did the girl who chose so unusual a pen name already hear a solution to her distress whispering within it: "learn, travel"?

\section{Three}

We know from the first page in Oh Millersville! that we are not reading the juvenilia of a successful author. In the one-page unsigned "Note" at the opening of the volume in which Hall explained that the name of the author remained a secret, other information was supplied that was even more dramatic:

This small volume is published with the consent of the author- 
ess, who, until recently reminded, had all but forgotten that she had ever been "inspired." She has written nothing since those far-off days; therefore, it is not likely that people will ever "travel to see the home of the poetess, Fern Gravel," as she once hoped they might do. $(\mathrm{Oh} 7)$

Hall's one-page note, impeccably imitating the slightly dithery tone of the amateur historian, is a fuzzy blend of polite gestures that are meaningless (yes, publishing the book has been okay'd by its writer) with blunt assertions that are heartbreaking (no one will even know where this writer lived because "Fern Gravel" never matured into a writer). Although it is placed at the beginning, it reads like a coda, announcing an unfulfilled life in a flat recitation that would be almost brutal in its insensitivity, except for the ironic fact that the woman who took Fern Gravel as a nom de plume has herself apparently forgotten what she had once dreamed of becoming. It is, then, Hall's final report from his worker-narrative documentary of the artist in America, and his most devastating indictment of a place that makes its past all too easy to erase. The sense of knowing how a narrative ends is "the crucial factor in shaping the affordances and constraints of emplotment," argues the historian James V. Wertsch, who specializes in the shape-shifting historical narratives of the U.S.S.R. that Soviet historians have had to rearrange at different times in the twentieth century. Whether there is an "upward or downward sweep of the plot" governs how we assess incidents in the overall (58). Hall's insistence on withholding any information about Fern's future development, with the exception of the knowledge that her artistry was left undeveloped, represents his ultimate commitment to a poetics based on carefully-calculated degrees of unfinishedness. Because we do not know what she became, we are unable to evaluate Oh Millersville! and we are left with a sharp sense of the obstacles to becoming an artist in America.

Yet in another sense, there is no vacuum. We know whom Fern grew into: she became James Norman Hall, superbly successful novelist and hoax-master extraordinaire who left behind small-town Iowa but took from it what he needed to find his way in the larger world. If the values that one learned in a region were only operable within that region, then the knowledge conveyed in poetry would be so limited as to be useless. What the artist knows and models for others is trying on other viewpoints, testing oneself, rebounding from failure, and cobbling together solutions as best one can. It is the idea of launching oneself into a poem without a sense of where it will lead but persevering, and finding a moment in which interior and exterior worlds richly condense. Wholly-imaginary poems may start out as vapid fantasies in which the writer is the heroic figure in a dream-like world, but they may also divulge moments that can reveal heretofore-invisible realities, limits and truths. Above all, what may be most important is the practice of attending to noises as if they might carry the music of human desire. For it is not predictable what moments will suddenly emerge into a sharpened clarity, unexpectedly attaining depth. It might be the thrill of imaginary alligators in an imaginary Mississippi, or the sober view of grade school children walking alongside each other in a funeral procession, or the crystal-clear sound of sleigh bells chiming on a cold winter's night. 


\section{Notes}

I am grateful to Paula Bennett, Mike Chasar, Jane Cogie, and Kevin Dettmar for discussions and commentary that helped complete this essay.

${ }^{1}$ Hall's book goes unnoticed even in K. K. Ruthven's otherwise exhaustive Faking Literature. The only study to acknowledge Oh Millersville! is William Jay Smith's The Spectra Hoax, a sensationalized exposé of spurious verse that spends six pages dismissing Hall's work as a laborious stunt. Though purporting to be an overview of twentieth-century poetic fakery, Smith's book is primarily a castigation of the audience for poetry whom he faults for their inadequate reading skills. Without the demand for quality that a knowledgeable audience imposes on poets, Smith fears that soon there will be no respect for the discipline of fine writing or the tradition of literary excellence. In 1961, the Beat poets were the scandalous byproduct of such audience unwariness. When Smith reissued his book in 2000, Language poets, John Ashbery and other experimentalists had proliferated in the shadows cast, he claims, by a readership out of control.

${ }^{2}$ Contemporary American composer Jonathan Chenette has treated Hall's poetry as if it were precisely this kind of text. In the vocal settings he has twice created (1990, 1992) for some Oh Millersville! poems, he captures the underlying complexity in apparently simple texts by showcasing a range of compositional styles. A program note explains that one setting evokes "Schubertian melodrama" while another is a simple "patriotic march." One is inspired by the "North Indian khyal genre of vocal music" while another "employs 12-tone rowforms in the melody with their mirror image in the accompaniment" ("Program Notes"). So detailed are Chenette's renderings that the cycle even features one poem, "Places," that appeared exclusively in Hall's 1946 essay.

\section{Works Cited}

Benjamin, Walter. "On the Concept of History." Walter Benjamin: Selected Writings, Vol. 4, 1938-1940. Ed. Howard Eiland and Michael W. Jennings. Trans. Edmund Jephcott. Cambridge: Harvard UP, 2003. 389-400.

DeKoven, Marianne. "Cultural Dreaming and Cultural Studies.” New Literary History 27:1 (1996): 127-144.

Fletcher, Angus. A New Theory for American Poetry: Democracy, the Environment, and the Future of Imagination. Cambridge: Harvard UP, 2004.

Hall, James Norman. "December in the Tropics." Atlantic Monthly 157:4 (April 1936): 500.

- ."The Ends of Being." Under a Thatched Roof. Boston: Houghton Mifflin, 1942.209-223.

—. "Fern Gravel: A Hoax and a Confession.” Atlantic Monthly 178:3 (Sept. 1946): 112-114.

-. [Fern Gravel.] Oh Millersville! Muscatine, IA.: The Prairie P, 1940.

-.My Island Home. Boston: Little, Brown, 1952.

—. "The Spirit of Place." Under a Thatched Roof. Boston: Houghton Mifflin, 1942.86-95.

Harrington, Joseph. Poetry and the Public: The Social Form of Modern U.S. 
Poetics. Middletown, CT.: Wesleyan UP, 2002.

McHale, Brian. "“A Poet May Not Exist': Mock-Hoaxes and the Construction of National Identity." The Faces of Anonymity. Ed. Robert Griffin. New York: Palgrave, 2003. 233-52.

Nelson, Cary. Repression and Recovery: Modern American Poetry and the Politics of Cultural Memory, 1910-1945. Madison: U of Wisconsin P, 1989.

- Revolutionary Memory: Recovering the Poetry of the American Left. New York: Routledge, 2001.

Newcomb, John Timberman. Would Poetry Disappear? American Verse and the Crisis of Modernity. Columbus, OH: Ohio State UP, 2004.

"Program Notes." Oh Millersville! 14 Slices of Small-Town Life for Soprano and Piano by Jonathan Chenette. Sheet music. 1990.

Rabinowitz, Paula. They Must Be Represented: The Politics of Documentary. London: Verso, 1994.

Ruthven, K. K. Faking Literature. London: Cambridge UP, 2004.

Smith, William Jay. The Spectra Hoax. Middletown: Wesleyan UP, 1961.

Stott, William. Documentary Expression and Thirties America. New York: Oxford, 1973.

Thompson, Ralph. “Books of the Times.” New York Times 6 January 1941: 13.

Wertsch, James V. Voices of Collective Remembering . Cambridge: Cambridge UP, 2002. 